\title{
The Adsorption Capacity and Geotechnical Properties of Modified Clay Containing SSA Used as Landfill Liner-Soil Materials
}

\author{
Haijun Lu, ${ }^{1,2}$ Yiqie Dong, ${ }^{2}{\text { Jixiang } \mathrm{Li}^{2},{ }^{2} \text { and Changhong Wang }}^{2}$ \\ ${ }^{1}$ State Key Laboratory of Geomechanics and Geotechnical Engineering, Institute of Rock and Soil Mechanics, \\ Chinese Academy of Sciences, Wuhan 430071, China \\ ${ }^{2}$ Institute of Poromechanics, Wuhan Polytechnic University, Wuhan 430023, China
}

Correspondence should be addressed to Haijun Lu; lhj_whpu@163.com

Received 6 April 2015; Revised 12 June 2015; Accepted 12 July 2015

Academic Editor: Yuangen Yang

Copyright ( 2015 Haijun Lu et al. This is an open access article distributed under the Creative Commons Attribution License, which permits unrestricted use, distribution, and reproduction in any medium, provided the original work is properly cited.

The potential of clay containing $0 \sim 5 \%$ sewage sludge ash (SSA) is assessed for use as a landfill liner-soil material. Low temperature $\mathrm{N}_{2}$ adsorption, batch adsorption, permeability, and unconfined compressive strength tests are performed to evaluate pore structure, adsorption capacity, hydraulic conductivity, and unconfined compressive strength of the clays. The pore size distribution of the modified clay containing SSA is mainly composed of micropores $(<2 \mathrm{~nm})$ and mesopores $(2 \sim 7 \mathrm{~nm})$. With the increasing of SSA from $0 \%$ to $5 \%$, the adsorption capacity of $\mathrm{Zn}(\mathrm{II})$ and $\mathrm{Cu}$ (II) to the clay increases $37 \%$ and $273 \%$, respectively. The hydraulic conductivity of modified clay is from $3.62 \times 10^{-8}$ to $2.17 \times 10^{-8} \mathrm{~cm} / \mathrm{s}$. At SSA $=3 \%$, the unconfined compressive strength of the clay reaches the maximum value of $601.1 \mathrm{kPa}$. After the clay containing SSA is contaminated by acid and alkali chemical solutions, the amount of mesopores and hydraulic conductivity increase. The adsorption capacity and unconfined compressive strength of contaminated clay decrease about $2 \sim 44 \%$ and $25.7 \sim 38.2 \%$, respectively. The modified clay containing SSA can meet the adsorption and geotechnical requirement of landfill liners.

\section{Introduction}

The pollution caused by the sewage sludge is one of the most highlighted environmental problems in China. According to related surveys, the national output of the wet sludge is $2.24 \times 10^{7} \mathrm{t}$, namely, $6.14 \times 10^{4} \mathrm{t}$ per day. However, half of the sewage sludge is not correctly disposed. The sewage sludge without innocuous treatment easily contaminates atmosphere, water, and soil. Nowadays, the properties of dry sludge and techniques of sludge disposing are investigated comprehensively $[1,2]$, though there are few researches in the resources utilization of the sewage sludge.

In view of the low cost and good hygiene condition, the liner system composed of the compacted clay is widely applied to design of the landfill. The structural stability of the liner system is one of the key factors to ensure the working of the system safely. He et al. found that the landfill leachate contains plenty of heavy metal elements and its $\mathrm{pH}$ values range from 4.5 to 9 [3]. If the system is under long-period of sustained leachate contamination, the liner system is so badly weakened that it generates potential threats to human health.

Many scholars used some materials to improve adsorption capacity of the liner system [4-6], such as coal ash, red mud, bentonite, and straw fiber. Sewage sludge ash (SSA) is a kind of porous material produced at the high temperature incineration. The SSA has relatively high specific surface area and ion-exchange capacity [7]. Moreover, the ash also has relatively high adsorption capacity on heavy metal ions, such as $\mathrm{Cd}(\mathrm{II}), \mathrm{Ni}(\mathrm{II})$ [8].

The objective of this paper is to evaluate the feasibility of the modified clay containing SSA used as the landfill liner-soil material. The transformations of pore structure of the modified clay are analyzed using the low temperature $\mathrm{N}_{2}$ adsorption tests. The adsorption capacity of $\mathrm{Zn}(\mathrm{II})$ and $\mathrm{Cu}(\mathrm{II})$ to the modified clay is investigated by batch tests. The hydraulic conductivity and strength properties of the 
TABLE 1: The physical properties of the clay.

\begin{tabular}{|c|c|c|c|c|c|c|c|c|}
\hline \multirow{2}{*}{$\rho_{d \max }\left(\mathrm{g} / \mathrm{cm}^{3}\right)$} & \multirow{2}{*}{$W_{\text {opt }}(\%)$} & \multirow{2}{*}{$W_{L}(\%)$} & \multirow{2}{*}{$W_{p}(\%)$} & \multirow{2}{*}{$I_{p}$} & \multicolumn{4}{|c|}{ Particle size distribution (\%) } \\
\hline & & & & & $>0.05(\mathrm{~mm})$ & $0.05 \sim 0.005(\mathrm{~mm})$ & $0.005 \sim 0.002(\mathrm{~mm})$ & $<0.002(\mathrm{~mm})$ \\
\hline 1.65 & 19 & 48.5 & 26.2 & 22.3 & 12 & 32 & 45 & 11 \\
\hline
\end{tabular}

TABLE 2: The chemical constituents of the clay (\%).

\begin{tabular}{lcccccc}
\hline $\mathrm{SiO}_{2}$ & $\mathrm{Al}_{2} \mathrm{O}_{3}$ & $\mathrm{Fe}_{2} \mathrm{O}_{3}$ & $\mathrm{CaO}$ & $\mathrm{MgO}$ & $\mathrm{K}_{2} \mathrm{O}$ & $\mathrm{Na}_{2} \mathrm{O}$ \\
\hline 58.42 & 25.23 & 0.24 & 0.51 & 0.12 & 5.32 & 2.67 \\
\hline
\end{tabular}

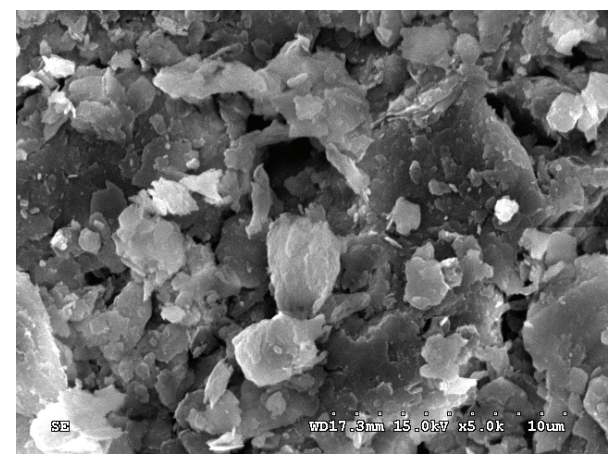

FIgURE 1: The microstructure of SSA $(5.0 \mathrm{k}, 10 \mu \mathrm{m})$.

modified clay are systematically determined by permeability and unconfined compressive strength tests.

\section{Materials and Methods}

2.1. Testing Materials. The clay and sewage sludge used in tests were obtained from a construction site and the Han-xi sewage treatment plant in Wuhan, China, respectively. The physical properties and chemical constituents of the clay and the basic physical properties of the sewage sludge are listed in Tables $1-3$, respectively.

The sludge was dried in the thermostatic temperature dry box at $105^{\circ} \mathrm{C}$ for $24 \mathrm{~h}$. After that, the sludge was incinerated in the Muffle furnace (Tianjin Mafuer Sci. \& Tech. Co., Ltd.) under the anaerobic condition at $850^{\circ} \mathrm{C}$ for $3 \mathrm{~h}$. The redbrown and grainy ash was sieved through the 200-mesh screen [9]. The chemical constituents of SSA are listed in Table 4 . The microstructure, pore volume, and pore size distribution of SSA are shown in Figures 1 and 2, respectively. It can be seen from Figures 1 and 2 that the SSA is irregular and porous, and every relic of SSA has small volume. The distribution of pore volume is uniform, and the pores from 2 to $4 \mathrm{~nm}$ have greater proportion.

\subsection{Testing Methods}

2.2.1. Low Temperature $\mathrm{N}_{2}$ Adsorption Tests. The clay was firstly broken into pieces and selected through the $2 \mathrm{~mm}$ screen. After that, the clay was mixed with 5\% SSA as modified clay $[10,11]$. According to the $\mathrm{pH}$ value of leachate, the chemical solutions ( $\mathrm{pH}=5,7$ and 9) were confected by the

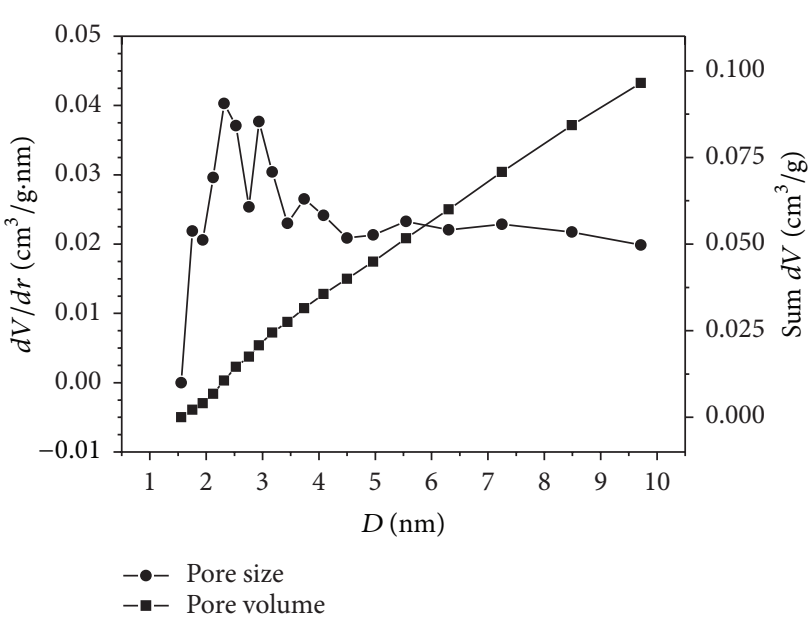

FIGURE 2: The pore volume and pore size distributions of SSA.

hydrochloric acid and sodium hydroxide. The modified clay was soaked in the solutions for 30 days. The clay was selected through the $2 \mathrm{~mm}$ round hole screen. The pore structure of the clay was investigated by JW-BK static nitrogen adsorption instrument (Beijing JWGB Sci. \& Tech. Co., Ltd.).

2.2.2. Batch Tests. Dry clay of $50.0 \mathrm{~g}$ was equally divided into four parts, and the four parts were mixed with $0 \%, 1 \%$, $3 \%$, and 5\% SSA, respectively. The mixed clay was soaked in $50 \mathrm{~mL} \mathrm{ZnCl}_{2}$ (aq) and $\mathrm{CuCl}_{2}$ (aq), respectively. To keep the range of $\mathrm{pH}$ value at $5-9$, the $\mathrm{HCl}$ and $\mathrm{NaOH}$ solutions were added into the $\mathrm{ZnCl}_{2}$ (aq). Similarly, the $\mathrm{pH}$ value of $\mathrm{CuCl}_{2}$ (aq) was kept at the range from 4 to 8 . The mixture was shaken in water bath instrument under the condition of $25^{\circ} \mathrm{C}, 150 \mathrm{r} / \mathrm{min}$. The concentrations of $\mathrm{Zn}$ (II) and $\mathrm{Cu}(\mathrm{II})$ in suspension solutions after centrifugation were measured by spectrophotometry (Shanghai Third Analytical Instruments Factory) according to GB 7467-87 DPC. The error of the colorimetric measurements was smaller than $4 \%$. The amount of $\mathrm{Zn}(\mathrm{II})$ and $\mathrm{Cu}(\mathrm{II})$ adsorbed by the soil particles was calculated based on the mass balance.

\subsubsection{Permeability and Unconfined Compressive Strength} Tests. The contents of SSA were $1 \%, 3 \%$, and $5 \%$ in the modified clay, respectively. The diameter and height of the clay sample were $61.8 \mathrm{~mm}$ and $40 \mathrm{~mm}$ in the permeability test, respectively. Additionally, the diameter and height of the soil samples were $39.1 \mathrm{~mm}$ and $80 \mathrm{~mm}$ in the unconfined compressive strength test, respectively. The density of the clay was $1.60 \mathrm{~g} / \mathrm{cm}^{3}$ and its moisture content was $19 \%$. The $\mathrm{HCl}$ and $\mathrm{NaOH}$ were applied to adjust the $\mathrm{pH}$ values $(5,6,8$, and 9) of the chemical solutions, respectively. The modified clay was soaked in chemical solutions for 30 days. 
TABLE 3: The basic physical properties of sludge.

\begin{tabular}{lcccc}
\hline $\mathrm{pH}$ & Proportion $(\mathrm{g} / \mathrm{ml})$ & Content of organic matter $(\%)$ & Moisture content (\%) & Porosity \\
\hline 6.96 & 1.24 & 43.2 & 80.3 & 3.36 \\
\hline
\end{tabular}

TABLE 4: The chemical constituents of SSA (\%).

\begin{tabular}{ccccccccccc}
\hline $\mathrm{SiO}_{2}$ & $\mathrm{Al}_{2} \mathrm{O}_{3}$ & $\mathrm{Fe}_{2} \mathrm{O}_{3}$ & $\mathrm{CaO}$ & $\mathrm{SO}_{3}$ & $\mathrm{P}_{2} \mathrm{O}_{5}$ & $\mathrm{~K}_{2} \mathrm{O}$ & $\mathrm{MgO}$ & $\mathrm{TiO}_{2}$ & $\mathrm{Na}_{2} \mathrm{O}$ & $\mathrm{Others}$ \\
\hline 45.5 & 16.6 & 8.11 & 6.64 & 6.61 & 5.72 & 4.45 & 3.90 & 0.98 & 0.83 & 0.66 \\
\hline
\end{tabular}

According to the standard of soil tests SL237-1999, the hydraulic conductivity and unconfined compressive strength were measured by the TST-55 permeameter and YYW-2 strain controlled unconfined pressure apparatus (Nanjing Ningxi Soil Instrument Co., Ltd.), respectively. All of the tests were repeated three times.

\section{Results and Discussion}

3.1. Pore Structure. Figure 3 shows the adsorption-desorption isotherm of the modified clay containing SSA. According to IUPAC classification method, the isotherm of clay belongs to the IV category. It is seen from Figure 3 that the adsorption isotherm is a bit of salient when the ratio of $P / P_{0}$ is smaller than 0.1 . In this stage, the adsorption mainly happens at the micropore wall of clay particles and SSA, and the adsorption amount also gradually achieves saturation in single layer. The adsorption amount gradually increases with the increase of the relative pressure from 0.1 to 0.65 . This elucidates the increase of the monolayer molecular amount of the large pore wall and multilayer adsorption in modified clay. The adsorption amount increases dramatically when $P / P_{0}$ is larger than 0.65 because the capillary condensation of $\mathrm{N}_{2}$ occurs in the macropores. The adsorption amount is unable to reach the ultimately saturated level owing to the existence of the pores larger than $10 \mathrm{~nm}$.

The hysteresis loop exists between the adsorption and desorption isotherms, and the differences of the loop shape stand for the differences of the pore structure. The two curves of the adsorption and desorption coincide with each other when $P / P_{0}$ is smaller than 0.25 , indicating that the micropores of the size of less than $1.38 \mathrm{~nm}$ (according to the Kelvin formula [12]) are sealed in one side and opened in the other side, and those of the size of more than $1.38 \mathrm{~nm}$ are opened in two sides [13]. Moreover, the adsorption amount of the clay contaminated by alkali solution with $\mathrm{pH}=9$ is apparently greater than that of the modified clay with contaminated acid solution with $\mathrm{pH}=5$. The area of the circular adsorption membrane of the clay in alkali solution is greater than that of the acid solution. The capillary condensation of the adsorption appears on the circular adsorption membrane of the pore wall.

On the basis of the standards from the International Theory and Application of Chemical Association (IUPAC), the pore sizes of porous media can be divided into three categories, that is, macropore $(>50 \mathrm{~nm})$, mesopore $(2 \mathrm{~nm} \sim$ $50 \mathrm{~nm})$, and micropore $(<2 \mathrm{~nm})$ [14]. Figure 4 depicts the

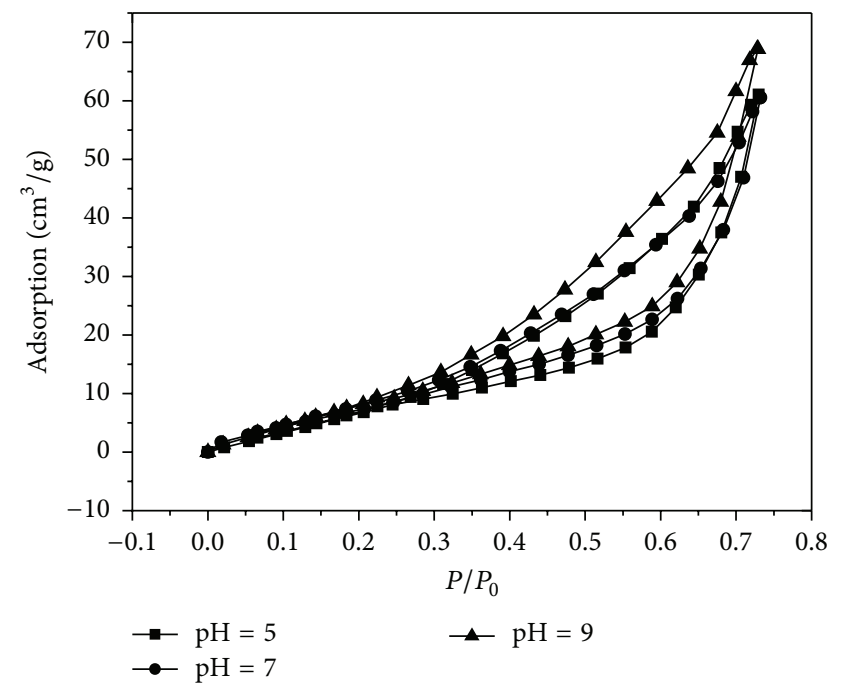

FIGURE 3: The adsorption-desorption isotherm of the modified clay containing SSA.

pore volume and pore size distribution of the modified clay containing SSA. It is observed from Figure 4 that the pore size distributions of the modified clay have wide double shoulder peaks, and the proportions of pore between $2 \mathrm{~nm}$ and $7 \mathrm{~nm}$ are relatively greater. The curves of the total pore volume of the modified clay tend to the straight lines. When the modified clays are contaminated by acid and alkali chemical solutions, the total pore volume slightly increases at the broad peak. The volumes of the pores between $3 \mathrm{~nm}$ and $7 \mathrm{~nm}$ increase significantly. However, the volumes of the pores smaller than $2 \mathrm{~nm}$ have no apparent changes. The amount of micropore $(<2 \mathrm{~nm})$ is decided by the interplanar crystal spacing, and the acid and alkali solutions have a little influence on the mineral lattice [13]. The distributions of the pores from $3 \mathrm{~nm}$ to $7 \mathrm{~nm}$ are uniform, and the double shoulder peaks of the clay are unobvious. This is attributed to the reason that the acid solution can easily corrode and destroy the mode of the lattice connection inside the minerals.

3.2. Adsorption Capacity. Figures 5 and 6 present the adsorption isotherms for the $\mathrm{Zn}(\mathrm{II})$ and $\mathrm{Cu}(\mathrm{II})$. The adsorption of $\mathrm{Zn}(\mathrm{II})$ and $\mathrm{Cu}(\mathrm{II})$ to all specimens is modeled as a Langmuir isotherm, and coefficients of determination $\left(R^{2}\right)$ are greater 


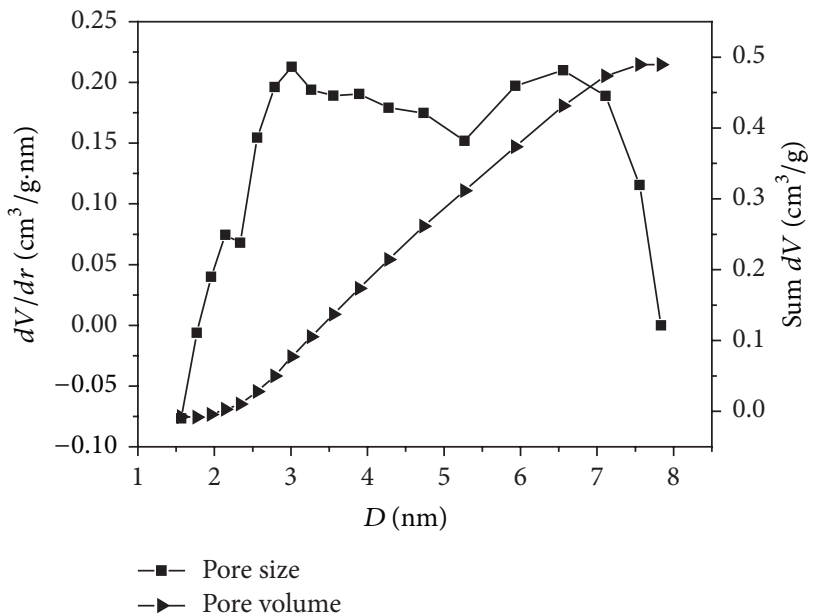

(a) $\mathrm{pH}=5$

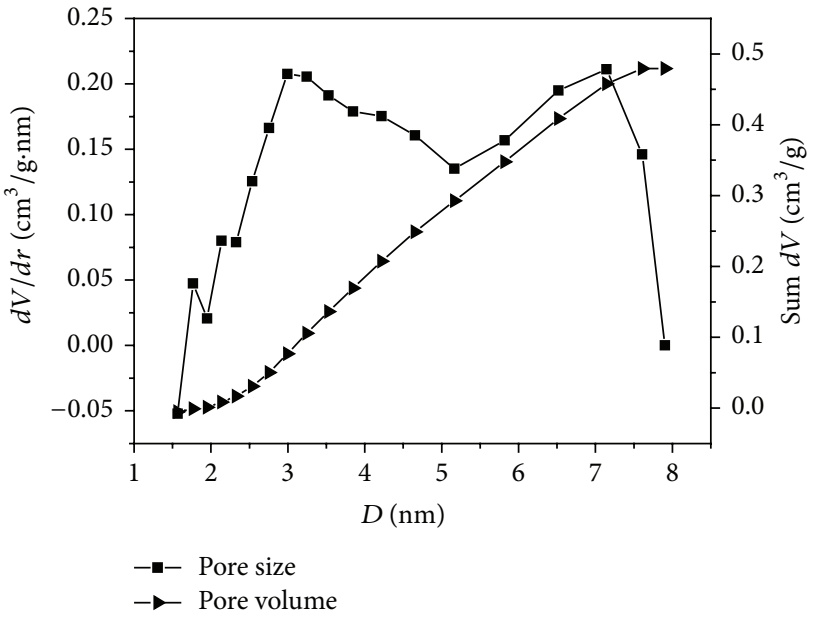

(b) $\mathrm{pH}=7$

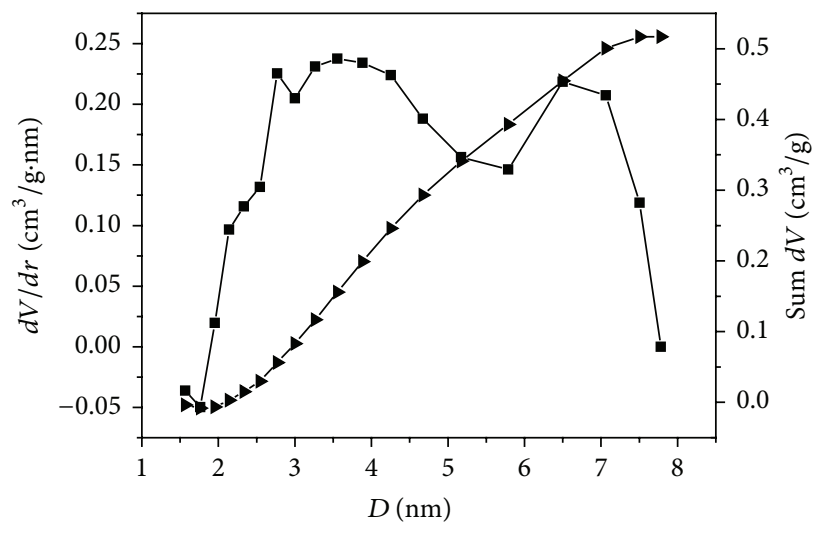

- - Pore size

$\rightarrow$ Pore volume

(c) $\mathrm{pH}=9$

FIGURE 4: The pore volume and pore size of the modified clay containing SSA.

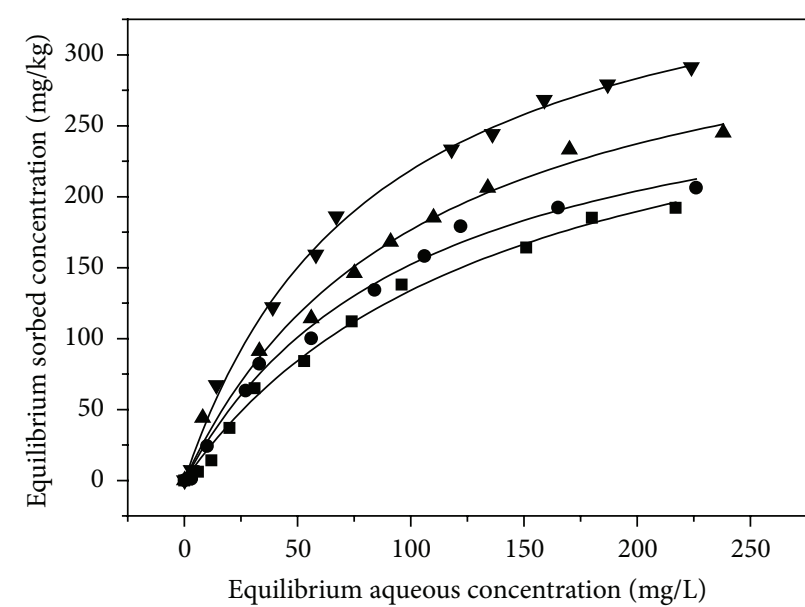

- $\mathrm{SSA}=0 \%$

- $\mathrm{SSA}=1 \%$
SSA $=3 \%$
SSA $=5 \%$

(a) $\mathrm{Zn}(\mathrm{II})$

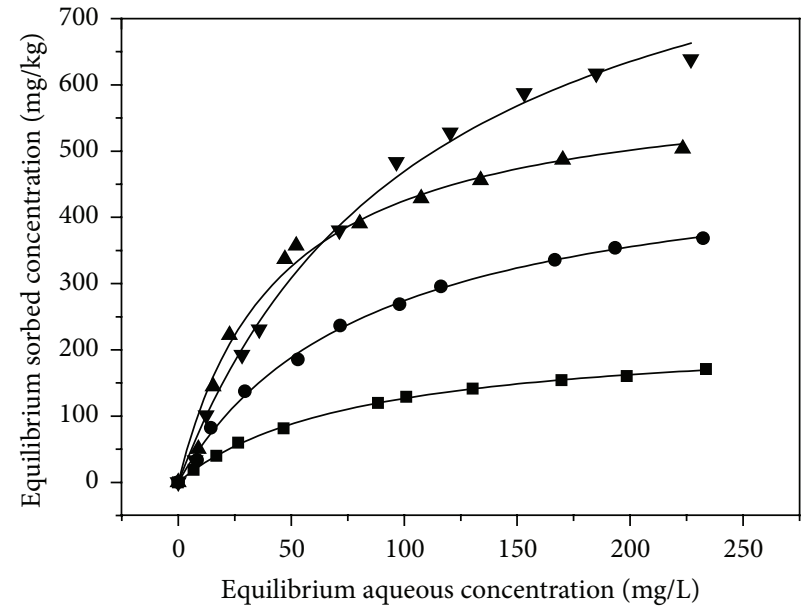

- $\mathrm{SSA}=0 \%$

- $\mathrm{SSA}=1 \%$

- $\mathrm{SSA}=5 \%$

(b) $\mathrm{Cu}(\mathrm{II})$

FIgURe 5: Adsorption isotherms for $\mathrm{Zn}$ (II) and $\mathrm{Cu}(\mathrm{II})$ on the modified clay containing SSA. 


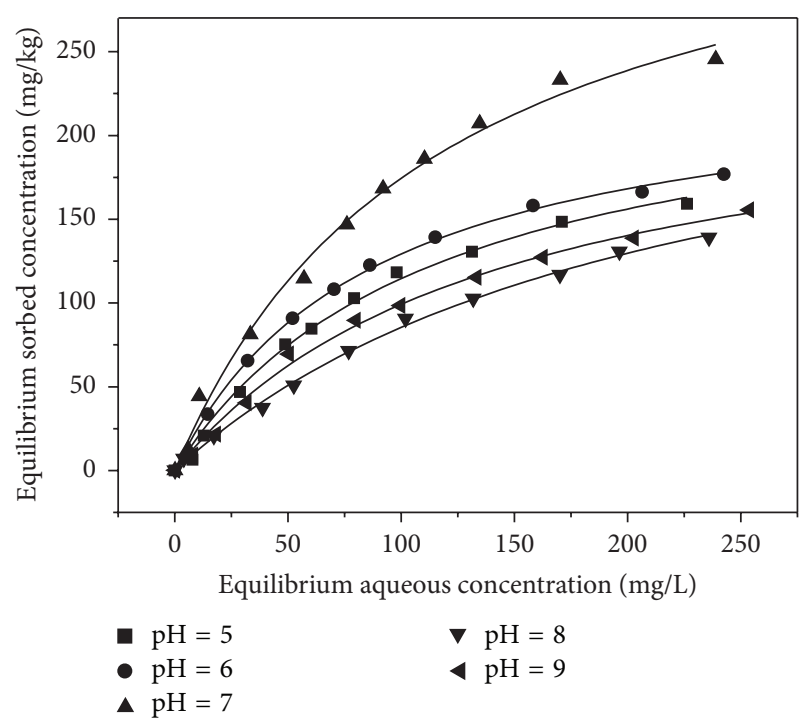

(a) $\mathrm{Zn}(\mathrm{II})$

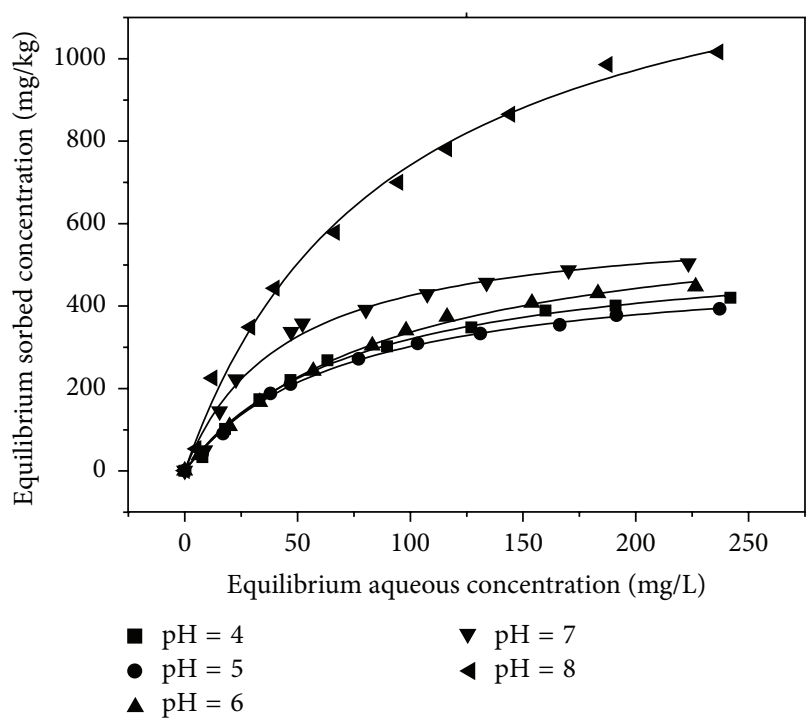

(b) $\mathrm{Cu}(\mathrm{II})$

FIgURE 6: Adsorption isotherms for $\mathrm{Zn}(\mathrm{II})$ and $\mathrm{Cu}(\mathrm{II})$ on the modified clay under acid and alkali chemical solutions.

TABLE 5: The values of isotherm parameters for the modified clay containing SSA.

\begin{tabular}{lcccc}
\hline Elements & $0 \%$ & $1 \%$ & $3 \%$ & $5 \%$ \\
\hline $\mathrm{Zn}(\mathrm{II})$ & & & & \\
$\quad b(\mathrm{~L} / \mathrm{mg})$ & 0.00702 & 0.00966 & 0.00885 & 0.0119 \\
$q_{m}(\mathrm{mg} / \mathrm{kg})$ & 324.633 & 309.325 & 378.250 & 401.959 \\
$R^{2}$ & 0.993 & 0.993 & 0.991 & 0.997 \\
$\mathrm{Cu}(\mathrm{II})$ & & & & \\
$\quad b(\mathrm{~L} / \mathrm{mg})$ & 0.0126 & 0.0118 & 0.0228 & 0.00913 \\
$q_{m}(\mathrm{mg} / \mathrm{kg})$ & 226.925 & 505.206 & 610.856 & 982.218 \\
$R^{2}$ & 0.999 & 0.997 & 0.986 & 0.995 \\
\hline
\end{tabular}

than 0.98 . The isotherm parameters for the $\mathrm{Zn}(\mathrm{II})$ and $\mathrm{Cu}(\mathrm{II})$ are given in Tables 5 and 6 .

It can be found from Figures 5(a) and 5(b) that the adsorption capacity of $\mathrm{Zn}$ (II) and $\mathrm{Cu}(\mathrm{II})$ increases with the content of SSA increasing. In Figure 5(a), the adsorption capacity of $\mathrm{Zn}$ (II) increases from 212.44 to $291.99 \mathrm{mg} / \mathrm{kg}$ when the equilibrium aqueous concentration is $250 \mathrm{mg} / \mathrm{L}$. Meanwhile, it is also seen from Figure 5(b) that the adsorption capacity of $\mathrm{Zn}(\mathrm{II})$ and $\mathrm{Cu}(\mathrm{II})$ increases from 171.04 to $638.08 \mathrm{mg} / \mathrm{kg}$ under the same equilibrium aqueous concentration. The amount of mesopores with one sealed in a side is large in the SSA. The specific surface area of the SSA is $11.31 \mathrm{~m}^{2} / \mathrm{g}$. Since there also exist a lot of adsorptive sites on surface, the modified clay has relatively high adsorption capacity of $\mathrm{Zn}$ (II) and $\mathrm{Cu}$ (II). By the configuration of the extranuclear electrons, $\mathrm{Zn}$ (II) is full electronic shell and has swell effect. The amount of extranuclear electrons outside $\mathrm{Zn}(\mathrm{II})\left([\mathrm{Ar}] 3 \mathrm{~d}^{10}\right)$ is larger than that of $\mathrm{Cu}(\mathrm{II})\left([\mathrm{Ar}] 3 \mathrm{~d}^{9}\right)$, and the radius of $\mathrm{Zn}(\mathrm{II})$ is also less than that of $\mathrm{Cu}(\mathrm{II})$.

Figure 6 suggests that when the equilibrium aqueous concentration is $250 \mathrm{mg} / \mathrm{L}$, with the increase of the acid and alkali concentration, the adsorption capacity of $\mathrm{Zn}$ (II) to the modified clay declines from 245.62 to $138.14 \mathrm{mg} / \mathrm{kg}$. When the $\mathrm{pH}$ value is between 4 and 7 , the adsorption capacity of $\mathrm{Cu}(\mathrm{II})$ is between 392.25 and $503.27 \mathrm{mg} / \mathrm{kg}$. At $\mathrm{pH}=8$, the adsorption capacity of $\mathrm{Cu}$ (II) to the modified clay rapidly is increased to $1015.67 \mathrm{mg} / \mathrm{kg}$. With the increasing of acid and alkali concentration, the micropore and the gap between the pores are damaged, resulting in mesopores or macropores increases. The amount of pores and specific surface area decline rapidly.

The charges on the surface of the adsorbent are determined by $\mathrm{pH}$ value of solutions [15]. With the increase of $\mathrm{pH}$, the concentration of $\mathrm{OH}^{-}$in the solution increases, which strengthens the repulsive force between the ions and weakened the adsorption capacity of $\mathrm{Zn}$ (II) to clay. At $\mathrm{pH}=$ 9 , it is easy to produce the precipitate $\mathrm{Zn}(\mathrm{OH})_{2}$. The influence of $\mathrm{pH}$ on the adsorption of $\mathrm{Cu}$ (II) to the modified clay is unobvious. When the temperature is $25^{\circ} \mathrm{C}$, the precipitating equilibrium constant of $\mathrm{Cu}(\mathrm{OH})_{2}\left(2.2 \times 10^{-20}\right)$ is much less than that of $\mathrm{Zn}(\mathrm{OH})_{2}\left(1.2 \times 10^{-17}\right)$. Therefore, it is much easier for the $\mathrm{Cu}(\mathrm{II})$ to produce the $\mathrm{Cu}(\mathrm{OH})_{2}$ precipitate. At $\mathrm{pH}=$ 4.5 , the precipitating procedure of $\mathrm{Cu}$ (II) gradually begins, and $\mathrm{Cu}(\mathrm{OH})_{2}$ precipitate appears.

3.3. Hydraulic Conductivity. Figure 7 shows the hydraulic conductivity of the modified clay containing SSA. It can be observed from Figure 7 that the hydraulic conductivity of the modified clay declines from $3.62 \times 10^{-8}$ to $2.17 \times 10^{-8} \mathrm{~cm} / \mathrm{s}$ with the increasing of SSA at $\mathrm{pH}=7$. Since the SSA has small particles and rough surface, when the water molecules contacted with the SSA particles, the catapult effect occurs and the water molecules enter the pore which is sealed in a side. Hence, the permeating distance of water molecules becomes longer and the outflow in unit time becomes smaller. 
TABLE 6: The values of isotherm parameters for the modified clay under acid and alkali chemical solutions.

\begin{tabular}{|c|c|c|c|c|c|c|}
\hline Elements & $\mathrm{pH}=4$ & $\mathrm{pH}=5$ & $\mathrm{pH}=6$ & $\mathrm{pH}=7$ & $\mathrm{pH}=8$ & $\mathrm{pH}=9$ \\
\hline \multicolumn{7}{|l|}{$\mathrm{Zn}(\mathrm{II})$} \\
\hline$b(\mathrm{~L} / \mathrm{mg})$ & & 0.00878 & 0.0116 & 0.00885 & 0.00464 & 0.00705 \\
\hline$q_{m}(\mathrm{mg} / \mathrm{kg})$ & & 244.983 & 240.535 & 378.250 & 269.093 & 239.488 \\
\hline$R^{2}$ & & 0.995 & 0.996 & 0.994 & 0.998 & 0.996 \\
\hline \multicolumn{7}{|l|}{$\mathrm{Cu}(\mathrm{II})$} \\
\hline$b(\mathrm{~L} / \mathrm{mg})$ & 0.0135 & 0.0145 & 0.0108 & 0.0228 & 0.0111 & \\
\hline$q_{m}(\mathrm{mg} / \mathrm{kg})$ & 566.992 & 508.639 & 646.465 & 610.856 & 1410.663 & \\
\hline$R^{2}$ & 0.996 & 0.998 & 0.998 & 0.986 & 0.995 & \\
\hline
\end{tabular}

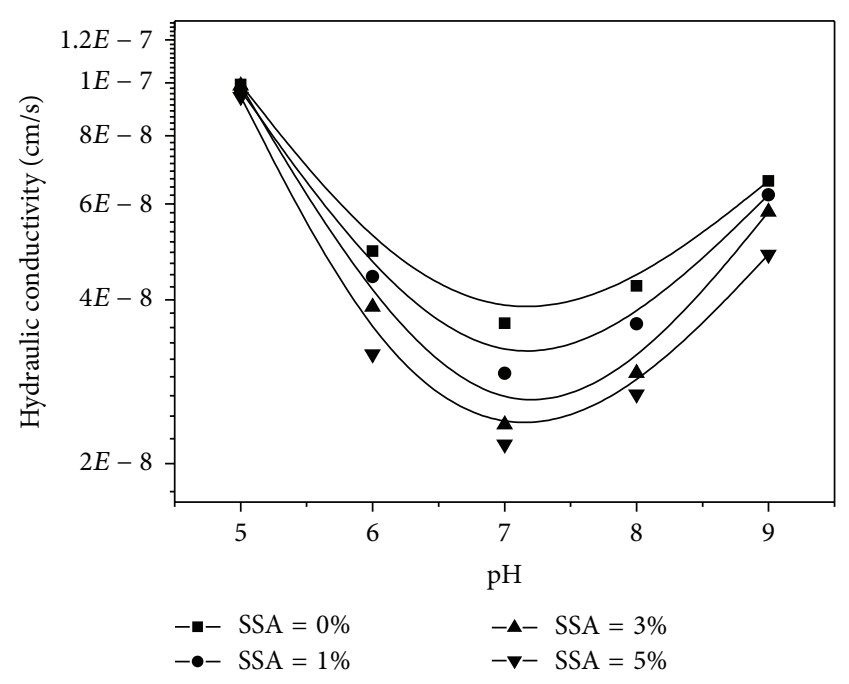

FIGURE 7: The hydraulic conductivity of the modified clay containing SSA.

After the clay containing SSA is contaminated by acid and alkali solutions, the hydraulic conductivity of modified clay increases about 2.2 4.3 times greater than before. And the increase degree of hydraulic conductivity of modified clay contaminated by acid chemical solution is much more obvious and the maximum value of it is $9.93 \times 10^{-8} \mathrm{~cm} / \mathrm{s}$. The results of the micropore structure tests indicate that the pore size of SSA is about 8 100 times that of the water molecules [16]. With the increased acid and alkali concentration, the pore structure of SSA shifts from seal in a side to open in both ends, which provides convenient conditions for the pore permeating. Besides, the space skeleton of clay particles also becomes looser, making the flowing of water molecules between the particles pores much easier [17].

3.4. Unconfined Compressive Strength. It is found that the unconfined compressive strength of modified clay increases with an increase of the content of SSA (Figure 8). The unconfined compressive strength of the clay first increases and then decreases with the increase of $\mathrm{pH}$. The modified clay containing 3\% SSA has the maximum unconfined compressive strength value of $601.1 \mathrm{kPa}$. The unconfined compressive strength of modified clay becomes weaker after the action

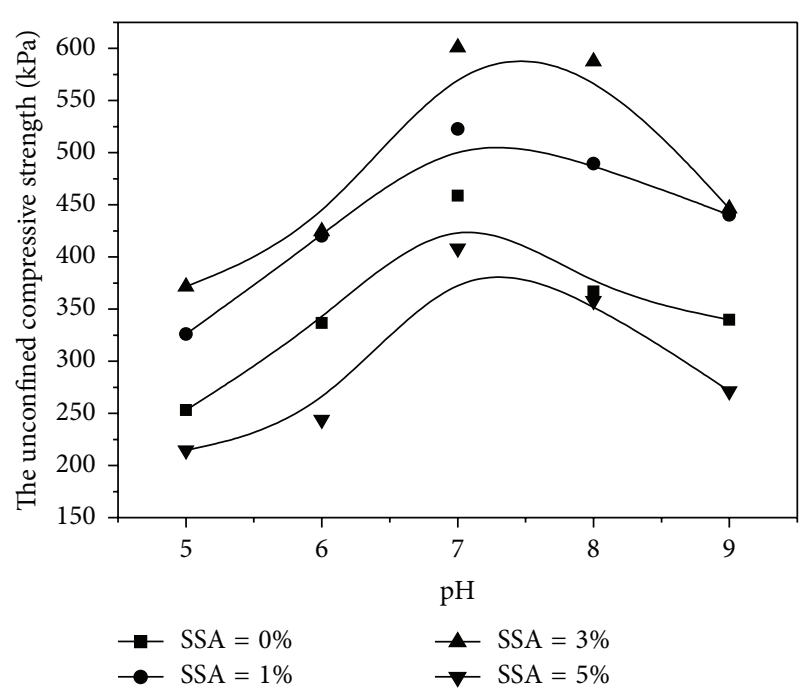

FIGURE 8: The unconfined compressive strength of the modified clay containing SSA.

of acid and alkali solution. For the modified clay containing $3 \%$ SSA contaminated by solutions with $\mathrm{pH}=5$ and $\mathrm{pH}=$ 9 , the unconfined compressive strength separately declines to $371.6 \mathrm{kPa}$ and $446.4 \mathrm{kPa}$.

The unconfined compressive strength has relation with factors, such as mineral component, shape, particle size, and cementation property $[18,19]$. After the clay is contaminated by acid and alkali solutions, the colloidal matter in the particles, such as organic-inorganic compounded colloid, free oxide, and soluble salt, is corroded. The structural bond force between the clay particles is weakened.

Daniel and Wu suggested that compacted soils used for landfill liners should have a minimum unconfined compressive strength of $200 \mathrm{kPa}$ [20]. As shown in Figure 8, the strength of all specimens meets the engineering requirement of $200 \mathrm{kPa}$. Thus, the method of adding SSA into compacted clay liners is effective measure to improve compressive strength of the liners.

\section{Conclusions}

The pores of the modified clay mainly have the micropores smaller than $2 \mathrm{~nm}$ and mesopores smaller than $7 \mathrm{~nm}$. 
The modified clay containing SSA has obvious adsorption capacity of heavy metal ions. With the increasing of SSA content from $0 \%$ to $5 \%$, the adsorption capacity of $\mathrm{Zn}$ (II) and $\mathrm{Cu}$ (II) increases $37 \%$ and $273 \%$, respectively. The hydraulic conductivity of the modified clay range from $3.62 \times 10^{-8}$ to $2.17 \times 10^{-8} \mathrm{~cm} / \mathrm{s}$. When the SSA content is $3 \%$, the unconfined compressive strength peak is $601.1 \mathrm{kPa}$.

After the clay is contaminated by acid and alkali chemical solutions, the distribution of pore size of clay becomes more uniform and the amount of pore between 2 and $7 \mathrm{~nm}$ increases. The adsorption of $\mathrm{Zn}$ (II) is declined 35 44\%, and the influence on the adsorption of $\mathrm{Cu}$ (II) is weakened. The hydraulic conductivity of modified clay increases about 2.2 4.3 times. But the hydraulic conductivity of all soil samples is still smaller than $1 \times 10^{-7} \mathrm{~cm} / \mathrm{s}$. The unconfined compressive strength of modified clay becomes smaller, but still larger than $200 \mathrm{kPa}$.

According to technical code for municipal soil waste sanitary landfill (CJJ17-2004), the modified clay containing SSA can meet the antiseepage and strength requirement of landfill liners. Consequently, improved clay containing SSA can be potentially used as landfill liner-soil materials.

\section{Conflict of Interests}

The authors declare that there is no conflict of interests regarding the publication of this paper.

\section{Acknowledgments}

This research was jointly funded by the Open Research Fund of State Key Laboratory of Geomechanics and Geotechnical Engineering, Institute of Rock and Soil Mechanics, Chinese Academy of Sciences (no. Z014007), National Natural Science Foundation of China (51474168), and Natural Science Foundation of Hubei Province (2014CFB889).

\section{References}

[1] D. D. Warnock, J. Lehmann, T. W. Kuyper, and M. C. Rillig, "Mycorrhizal responses to biochar in soil: concepts and mechanisms," Plant and Soil, vol. 300, no. 1-2, pp. 9-20, 2007.

[2] C.-H. Cheng, J. Lehmann, J. E. Thies, S. D. Burton, and M. H. Engelhard, "Oxidation of black carbon by biotic and abiotic processes," Organic Geochemistry, vol. 37, no. 11, pp. 1477-1488, 2006.

[3] P.-J. He, Z. Xiao, L.-M. Shao, J.-Y. Yu, and D.-J. Lee, "In situ distributions and characteristics of heavy metals in full-scale landfill layers," Journal of Hazardous Materials, vol. 137, no. 3, pp. 1385-1394, 2006.

[4] I. M. C. Lo, R. K. M. Mak, and S. C. H. Lee, "Modified clays for waste containment and pollutant attenuation," Journal of Environmental Engineering, vol. 123, no. 1, Article ID 12849, pp. 25-32, 1997.

[5] H.-J. Lu, M.-T. Luan, J.-L. Zhang, and Y.-X. Yu, "Study on the adsorption of $\mathrm{Cr}(\mathrm{VI})$ onto landfill liners containing granular activated carbon or bentonite activated by acid," Journal of China University of Mining \& Technology, vol. 18, no. 1, pp. 125130, 2008.
[6] S. Ghosh, S. Mukherjee, A. Z. Al-Hamdan, and K. R. Reddy, "Efficacy of fine-grained soil as landfill liner material for containment of chrome tannery sludge," Geotechnical and Geological Engineering, vol. 31, no. 2, pp. 493-500, 2013.

[7] H. C. Xu, H. Zhang, L. M. Shao, and P. J. He, "Fraction distributions of phosphorus in sewage sludge and sludge ash," Waste and Biomass Valorization, vol. 3, no. 3, pp. 355-361, 2012.

[8] M. Belmonte, J. Decap, M. Martínez, and G. Vidal, "Effect of aerobic sludge with increasing level of adaptation on abietic acid biodegradation," Bulletin of Environmental Contamination and Toxicology, vol. 77, no. 6, pp. 861-867, 2006.

[9] J.-S. Li, Q. Xue, P. Wang, and L. Liu, "Adsorption properties of municipal sludge biochar for soluble heavy metals," Research of Environmental Sciences, vol. 26, no. 11, pp. 1246-1251, 2013.

[10] S. Suzuki, M. Tanaka, and T. Kaneko, "Glass-ceramic from sewage sludge ash," Journal of Materials Science, vol. 32, no. 7, pp. 1775-1779, 1997.

[11] Z. Hongling, S. Lina, and S. Tieheng, "Solubility of trace elements and heavy metals from stabilized sewage sludge by fly ash," Bulletin of Environmental Contamination and Toxicology, vol. 83, no. 5, pp. 752-756, 2009.

[12] H.-L. Yao, "Some considerations about the concept of matric suction and questions related to matric suction," Rock and Soil Mechanics, vol. 26, no. 1, pp. 67-70, 2005.

[13] X. G. Zhang, H. Wu, and N. P. Yi, "Experiment study to city area water-soil interaction and soil structural change," Journal of Guangxi University, vol. 29, no. 1, pp. 39-43, 2004.

[14] B. D. Zdravkov, J. J. Čermák, M. Šefara, and J. Janků, "Pore classification in the characterization of porous materials: a perspective," Central European Journal of Chemistry, vol. 5, no. 2, pp. 385-395, 2007.

[15] D. Kołodyńska, R. Wnetrzak, J. J. Leahy, M. H. B. Hayes, W. Kwapiński, and Z. Hubicki, "Kinetic and adsorptive characterization of biochar in metal ions removal," Chemical Engineering Journal, vol. 197, pp. 295-305, 2012.

[16] S. C. Pan and D. H. Tseng, "Sewage sludge ash characteristics and its potential applications," Water Science and Technology, vol. 44, no. 10, pp. 261-267, 2001.

[17] S. Yariv and I. Lapides, "The effect of mechanochemical treatments on clay minerals and the mechanochemical adsorption of organic materials onto clay minerals," Journal of Materials Synthesis and Processing, vol. 8, no. 3-4, pp. 223-233, 2000.

[18] G. B. Liu and H. J. Liu, Soil Mechanics and Soil Mechanics, Science Press, Beijing, China, 2009.

[19] Z.-J. Feng, C. Cheng, T.-W. Wang, and X.-F. Liu, "Effect of microstructural changes of plate-like saline soil on its strength in extremely arid desert area," Chinese Journal of Geotechnical Engineering, vol. 33, no. 7, pp. 1142-1145, 2011.

[20] D. E. Daniel and Y. K. Wu, "Compacted clay liners and covers for arid sites," Journal of Geotechnical Engineering, vol. 119, no. 2, pp. 223-237, 1993. 

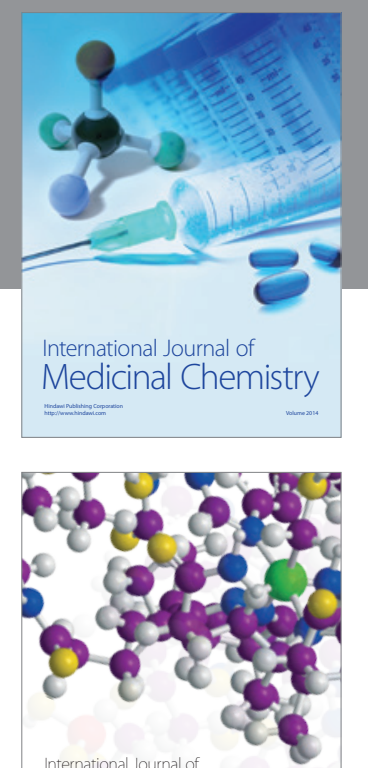

\section{Carbohydrate} Chemistry

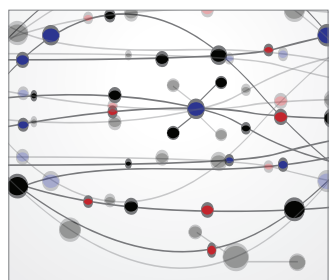

The Scientific World Journal
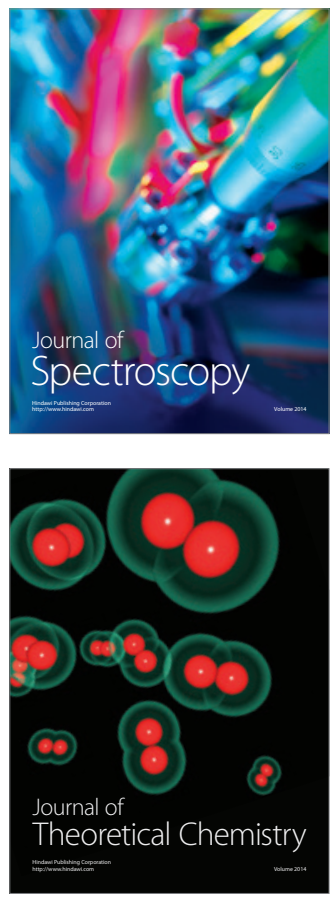
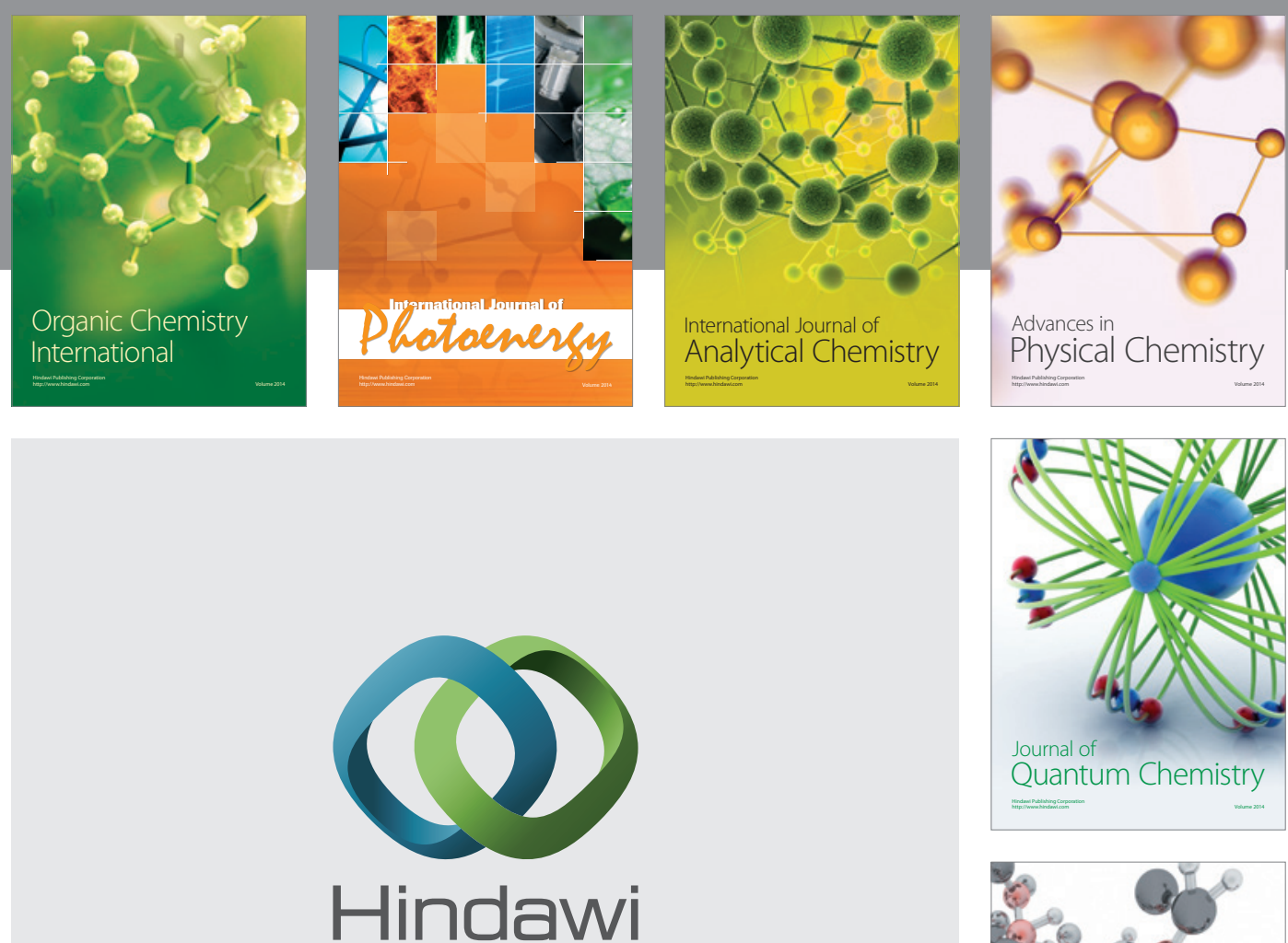

Submit your manuscripts at

http://www.hindawi.com

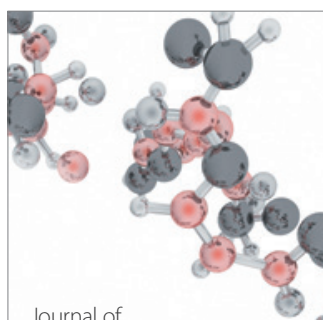

Analytical Methods

in Chemistry

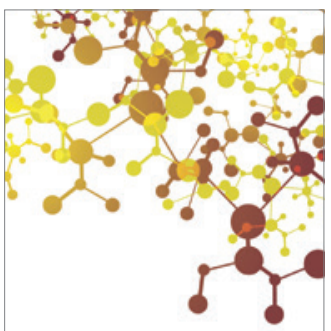

Journal of

Applied Chemistry

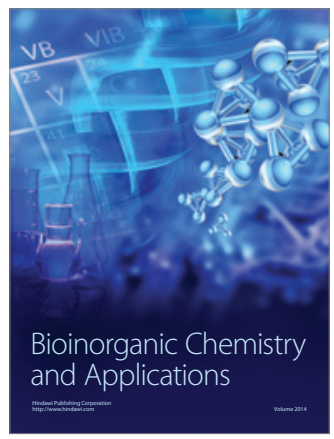

Inorganic Chemistry
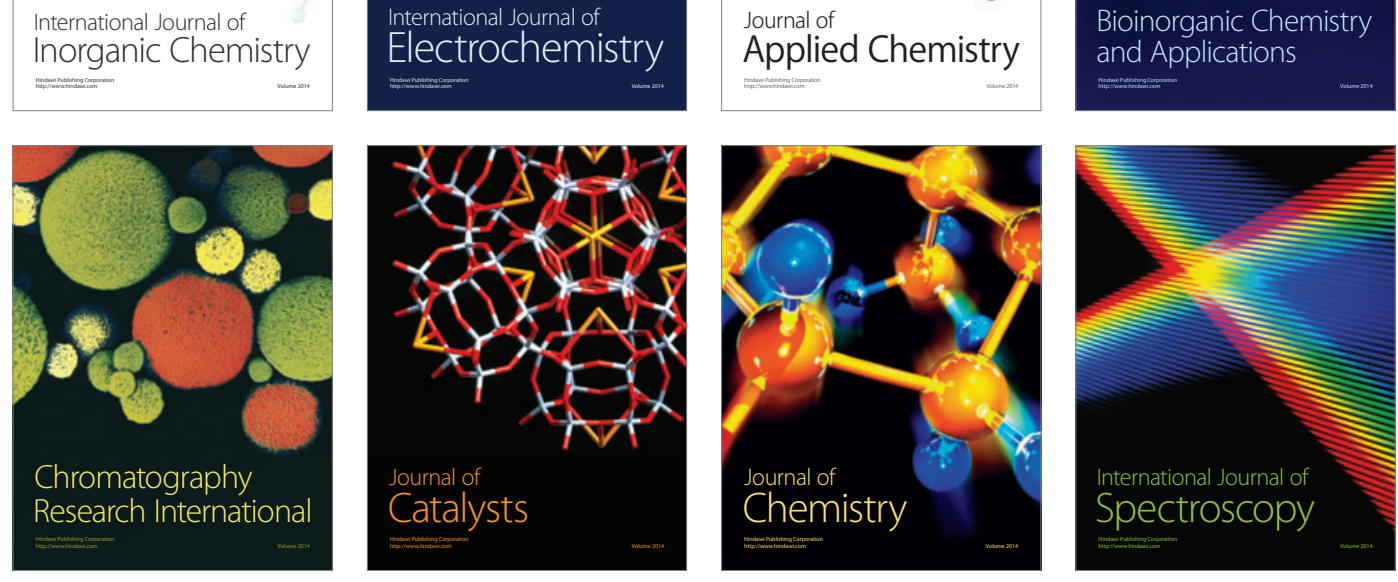